\title{
ANALISIS LAPORAN KEUANGAN PADA BANK RAKYAT INDONESIA DAN BANK NEGARA INDONESIA DI TINJAU DARI ANALISIS CAMEL
}

\author{
Yulia S.Hari' ${ }^{1}$, Roy.I.J.Pangkey ${ }^{2}$, Aprili.Bacilius ${ }^{3}$ \\ Akuntansi, FE Universitas Negeri Manado, Tondano, Akuntansi, FE Universitas Negeri Manado, Tondano, \\ Akuntansi, FE Universitas Negeri Manado, Tondano \\ e-mail: juliahari2015@gmail.com \\ Diterima:9 April 2021, Disetujui: 25 Agustus 2021
}

\begin{abstract}
ABSTARK
Tujuan riset ini merupakan guna mengenali gimana kinerja keuangan PT. Bank Rakyat Indonesia (Persero) Tbk serta PT. Bank Negeri Indonesia ( Persero) Tbk dengan memakai prosedur CAMEL (Capital, Assets, Management, Earning, Liquidity) periode 2014 hingga 2018. Metode yang digunakan adalah metode deskriptif kuantitatif. Hasil analisis laporan keuangan PT. Bank Rakyat Indonesia (Persero) Tbk serta PT. Bank Negara Indonesia (Persero) Tbk bersumber pada metode CAMEL mendapatkan predikat sehat sejak tahun 2014 sampai 2018. Sehingga PT. Bank Rakyat Indonesia (Persero) Tbk dapat menunjukkan prestasi peningkatannya pada rasio CAR, KAP, ROA, dan LDR sedangkan PT. Bank Negara Indonesia (Persero) Tbk menunjukkan prestasinya pada rasio NPM dan $L D R$. Efektivitas dari kedua bank ini memiliki ketahanan yang baik dalam menghadapi gejolak perekonomian saat ini sehingga nilai kesehatan yang dibentuk menunjukkan kedua bank tersebut dapat menjalankan fungsinya dengan baik.
\end{abstract}

Kata kunci: kinerja keuangan, kesehatan bank, CAMEL

\begin{abstract}
The purpose of this research is to find out how the financial performance of PT. Bank Rakyat Indonesia and PT. Bank Negara Indonesia using the CAMEL method (capital, assets, management, earnings, liquidity) for the period 2014 to 2018 . The method used is descriptive method which is quantitative in nature. With this method can help obtain data in the form of financial reports that are reviewed, analyzed, and interpreted systematically based on facts found to obtain an overview of the financial performance of BRI and BNI banks. The results of the analysis of the financial statements of PT. Bank Rakyat Indonesia and PT. Bank Negara Indonesia based on the ratio in the CAMEL method have received a healthy predicate from 2014 to 2018 , so that BRI bank shows an increase in the ratio of CAR, KAP, ROA, and LDR while BNI bank shows its achievements. on the ratio of NPM and LDR. The effectiveness of these two banks has good resilience in facing the current economic turmoil so that the soundness value established indicates that the two banks can carry out their functions properly.
\end{abstract}

Keywords: financial performance, bank soundness, CAMEL

\section{PENDAHULUAN}

Industri keuangan menjadi salah satu industri yang krusial dalam suatu negara. Industri keuangan khususnya perbankan adalah industri yang dibutuhkan dalam aktivitas transaksi keuangan disemua lapisan masyarakat. Sebagai lembaga perantara, perbankan memiliki peran yang sangat penting dalam memenuhi kebutuhan modal kerja dan investasi pada sektor riil. Oleh karenanya, fungsi utama perbankan dalam infrastruktur kebijakan makroekonomi memang dalam konteks bagaimana uang meningkatkan nilai tambah ekonomi secara efektif(Camel et al., 2016). Perbankan adalah tulang punggung dalam menyusun sistem perekonomian serta keuangan di Indonesia sebab dapat berfungsi sebagai intermediary institution ialah lembanga yang bias menyalurkan kembali dana yang dipakai oleh unit ekonomi yang surplus kepada unit ekonomi yang memerlukan bantuan dana ataupun defisit (Science, 2019). Indonesia banyak sekali jenis-jenis bank yang ada di antaranya bank kepunyaan negeri, bank swasta nasional dan bank asing. Bank umum milik negara memiliki peran ganda yaitu keuntungan (profit oriented) dan agen pembangunan negara (social 
oriented). Oleh karena itu, bank milik negara dituntut agar dapat mengelola asset negara dengan baik. Ada beberapa bank umum milik negara di Indonesia, diantaranya adalah Bank Mandiri, Bank BTN, Bank BRI dan Bank (BNI). Dari keempat bank tersebut bank BRI dan bank BNI merupakan bank yang sangat di kenal masyarakat karena kedua bank ini memiliki banyak cabang dan dapat di temui di berbagai daerah di Indonesia.

(Pada et al., 2017) Laporan keuangan ialah alat yang sangat penting untuk bisa mendapatkan informasi yang berhubungan dengan posisi keuangan dan hasil yang sudah dicapai oleh perusahaan yang bersangkutan. Informasi keuangan tersebut akan lebih berarti untuk pihak- pihak yang berkepentingan apabila informasi tersebut bisa diperbandingkan untuk dua periode ataupun lebih.(UMA, 2013) Dengan menganalisis laporan keuangan akan sangat membantu perusahaan untuk mengestimasi tingkat risiko yang dihadapi, uncertainty dan dapat berkontribusi menghasilkan perumusan rencana yang lebih baik.(v. M. buyanov, 1967)

Saat ini istilah bank sehat dan tidak sehat sangat populer. Untuk mengukur tingkat kesehatan suatu bank dapat dilakukan dengan menganalisis CAMEL yang di bagi dari capital di ukur untuk mengetahui kecukupan modal dengan menutupi adanya kemungkinan kegagalan dalam pemberian kredit yang telah di proksikan pada modal terhadap aktiva tertimbang menurut risiko, asset di proksikan dengan rasio aktiva produktif,management meliputi manajemen umum dan manajemen resiko di proksikan pada rasio net profit margin, earning mampunya perusahaan untuk mendapatkan laba dari semua sumber kegiatan misalnya penjualan, kas, modal, dan sebagainya yang telah di proksikan dengan return on asset dan liquidity dapat dikatakan likuid apabila memenuhi kewajiban utang dan permintaan kredit yang di proksikan dengan load to deposite rasio bank BRI telah menjadi bank paling berharga di Asia Tenggara. Begitu juga dengan PT. Bank Negara Indonesia (Persero) Tbk telah menggunakan berbagai cara untuk selalu menjaga dan meningkatkan kinerja keuangannya agar semua kekurangan yang ada segera di atasi dan menjadi bank yang sesuai dengan visi PT. Bank Negara Indonesia (Persero) Tbk yaitu menjadi lembaga keuangan dengan pelayanan dan kinerja yang sangat baik. Bank BNI mengalami penurunan laba di tahun 2015 di bandingkan tahun sebelumnya. Masalah pada bank BNI membuat kepercayaan masyarakat terhadap bank tersebut menurun sehingga banyak masyarakat yang ragu untuk menyimpan dana mereka. Bank BNI selama tahun 2014 hingga 2018 telah mengalami kredit bermasalah.

Bank merupakan industri komersial yang wujudnya memenuhi kebutuhan warga akan kredit, baik uang yang mereka terima dari orang lain ataupun dengan menghasilkan uang baru dalam wujud uang kertas ataupun koin. UU RI No.10 tahun 1998, mengatakan bahwa bank ialah badan usaha yang menghimpun dana dari warga dalam wujud simpanan serta menyalurkan kepada warga dalam rangka meningkatkan taraf hidup rakyat banyak

Melalui pembahasan ini bisa disimpulkan dimana bank berperan sebagai kolektor, dan penerbit dana masyarakat berupa giro, tabungan, deposito dan simpanan kredit, serta mendorong transaksi perdagangan pembayaran masyarakat. Laporan keuangan adalah memberikan informasi mengenai data perusahaan dalam periode yang ditentukan. Tujuan laporan keuangan ialah dapat memberikan informasi yang bermanfaat bagi investor dan kreditor untuk meramalkan, membandingan, dan menilai potensi arus kas yang akan di terima dalam jumlah waktu dengan ketidakpastian. Kinerja keuangan adalah analisis yang dirancang untuk bias melihat sampai dimana suatu perusahaan dapat melakukan dengan baik aturan pelaksanaan keuangannya. Menurut Sutrisno, kinerja keuangan perusahaan merupakan pencapaian perusahaan dalam satu periode untuk mencapai tingkat kesehatan perusahaan tersebut. BI No. 13/.2011 mengenai penilaian tingkat kesehatan bank umum sehingga bank wajib melakukan penilaian sendiri dengan menggunakan pendekatan risiko baik secara individual maupun konsolidasi. Menurut UU No.14 Tahun 1967 Pasal 1 mengenai Pokokpokok Perbankan, "bank merupakan lembaga keuangan yang usaha pokoknya membagikan kredit dan jasa dalam lalu lintas pembayaran dan peredaran uang."(Janeiro, 2018) 
Menurut sawir (2005:6) analisis keuangan membutuhkan beberapa tolak ukur untuk menilai kondisi keuangan dan prestasi perusahaan maka tolak ukur yang dipakai adalah rasio atau indeks, yang menghubungkan dua data keuangan satu dengan yang lain. Analisis rasio keuangan yang dihubungkan dengan unsur neraca dan perhitungan laba rugi satu dengan yang lainnya, dapat menggambarkan tentang sejarah perusahaan dan posisi keuangannya saat ini. Analisis rasio dapat juga memungkinkan manajemen keuangan memperkirakan reaksi para kreditor dan investor serta memberikan pandangan tentang bagaimana kira-kira dana diperoleh.(Manajemen Keuangan: Sebagai Dasar Pengeambilan Keputusan Bisnis - Rajawali ... - Google Books, n.d.)

Menurut Standar Akuntansi Keuangan laporan keuangan adalah proses pelaporan keuangan yang lengkap meliputi neraca, laba rugi, laporan perubahan posisi keuangan yang bisa disajikan melalui laporan arus kas, atau laporan arus dana, catatan dan laporan lain serta materai penjelasan yang adalah bagian integral laporan keuangan. Selain itu termasuk juga jadwal dan informasi tambahan yang berkaitan dengan laporan tersebut, misalnya informasi keuangan segmen industry dan geografis serta pengungkapan pengaruh perubahan harga (Ikatan Akuntansi Indonesia,2009). Dari pengertian di atas dapat dikatakan laporan keuangan mencerminkan semua transaksi usaha sepanjang waktu yang menghasilkan baik peningkatan maupun penurunan bersih nilai ekonomibagi pemilik modal. Maka laporan keuangan adalah media yang sangat penting untuk bisa menilai prestasi dan kondisi ekonomi suatu periode perusahaan (Manajemen et al., 2017). Hadirnya lembaga keuangan ini bisa memfasilitasi arus peredaran uang dalam perekonomian, baik uang dari individu investor untuk dikumpulkan dalam bentuk tabungan sehingga resiko bagi para investor kembali pada lembaga keuangan yang menyalurkan dana dalam bentuk pinjaman utang kepada yang membutuhkan.(Mandiri, 2012). Jelasnya ialah laporan keuangan dapat memberikan informasi keuangan pada pihak dalam dan luar perusahaan yang memiliki kepentingan terhadap perusahaan. (Analisis Laporan Keuangan - Google Books, n.d.)

Indikator kinerja keuangannya meliputi modal, aktiva, rentabilitas, dan likuiditas. Tujuan pengukuran kinerja keuangan perusahaan adalah mengetahui tingkat likuiditas yang menunjukan kemampuan perusahaan untuk bisa memenuhi kewajiban keuangan yang harus di selesaikan pada saat dikumpulkan. Mengetahui tingkat solvabilitas yang menunjukan kemampuan perusahaan untuk memenuhi kewajiban finansialnya jika perusahaan telah dilikuidasi, baik jangka pendek maupun jangka panjang. Tingkat profitabilitas dapat menunjukkan kemampuan perusahaan dalam menghasilkan keuntungan selama periode yang ditentukan.

Kesehatan suatu bank adalah mementingkan semua pihak yang terkait baik pemilik, pengelola bank, masyarakat, pengguna jasa bank dan Bank Indonesia sebagai otoritas pengawasan bank. Suatu cara perbankan dalam mengetahui keadaan perusahaan yang tidak sehat sehingga akan berdampak pada fungsi bank sebagai lembaga intermediasi yang tidak berfungsi dengan optimal. Terhambatnya fungsi intermediasi maka alokasi serta penyediaan dana dari perbankan untuk kegiatan investasi dan membiayai dalam perekonomian menjadi terhabat.(Pada et al., 2017) Analisis data sangatlah penting dalam penelitian karena bisa memberikan arti yang sangat berguna untuk memecahkan masalah penelitian. Tujuannya yaitu untuk menyederhanakan data ke dalam bentuk yang mudah dibacakan. Hal ini dimaksudkan untuk mendapatkan gambaran yang sangat jelas dari kegiatan yang telah diteliti.(Lhokseumawe et al., 2010)

Tingkat kesehatan bank adalah indikator yang sangat penting untuk bagian pemilik modal, nasabah maupun OJK sebagai pemilik otoritas dalam mengawasi bank. Tingkat kesehatan bank dinilai melalui indikator. Indikator yang dijadikan bahan penilaian ialah laporan keuangan yang telah diterbitkan oleh bank yang bersangkutan (Jati, 2020). Kegiatan utama bank yaitu melaksanakan penghimpunan dan penyaluran dana. Kegiatan penghimpunan dana bersumber dari modal sendiri, dari deposan atau nasabah, pinjaman melalui bank lain maupun Bank Indonesia, dan dari sumber lainnya. Sedangkan, kegiatan penyaluran dana bisa 
dilaksanakan dengan berbagai macam, misalnya penyaluran kredit, kegiatan investasi dalam bentuk aktiva tetap dan inventaris. Sebagian besar kegiatan penghimpunan dana bank berasal dari simpanan nasabah dengan bentuk simpanan tabungan, deposito berjangka dan giro. Simpanan nasabah biasa disebut dengan Dana Pihak Ketiga (DPK).(Dwi Safrisal.Pdf, n.d.) Salah satu faktor yang mempengaruhi nilai perusahaan adalah kinerja keuangan. Kondisi keuangan perusahaan pada satu periode tertentu berguna untuk mengetahui bagaimana proses pertumbuhan perusahaan tersebut baik atau tidak. Peran lembaga keuangan sangat penting serta berstrategis, agar peran masyarakat dalam membiayai pembangunan dapat ditingkatkan. Pengukuran kinerja menggunakan badan usaha untuk bisa melakukan perbaikan atas kegiatan operasionalnya agar bisa bersaing dengan yang lain.(UMA, 2013) baik buruk kinerja keuangan bank bisa di analisis dengan rasio keuangan CAMEL yang telah disesuaikan oleh surat keputusan direksi BI No.30/11/KEP/DIR tanggal 30 april 1997 mengenai cara menilai tingkat kesehatan bank umum. Begitu juga dengan menilai kinerja keuangan bank biasanya CAMEL memiliki beberapa aspek dalam menilai tingkat kesehatan bank antara lain Capital, Assets, Management, Earning, dan Liquidity.(Istikomah, 2014)

PT. Bank Rakyat Indonesia telah berdiri di Indonesia pada tahun 1895 dan terletak di Purwokerto, Jawa Tengah, oleh Raden Bei Aria Wirjaatmadja. Purwokerto merupakan penerus ibu kota Karesidenan Banyumas, dan kemudian pendopo Si Panji beralih tempat dari Kota Banyumas ke Kota Purwokerto. Kota ini memiliki peran yang berfungsi dalam sejarah perbankan di Indonesia. Selain itu, kota ini juga berperan dalam perjuangannya untuk mempertahankan kemerdekaan Indonesia. Banyak monumen pelajar yang telah berjasa dalam perjuangan kemerdekaan RI.

Bank BNI awalnya didirikan di Indonesia sebagai Bank sentral dengan nama "Bank Negara Indonesia" dengan peraturan pemerintah mengganti UU No.2 tahun 1964 tanggal 5 juli 1946. Selanjutnya berdasarkan UU No.17 tahun 1968 bank BNI ditetapkan menjadi "Bank Negara Indonesia 1946" dan statusnya menjadi BUMN (Bank Umum Milik Negara). Kemudian, peran Bank BNI yang diberi tanggungjawab untuk memperbaiki ekonomi rakyat dan berpartisipasi dalam membangun nasional dilakukan oleh UU No.17 tahun 1968 tentang BNI 1946.

Laba bank BNI periode 2015 mengalami penurunan dibandingkan dengan tahun sebelumnya. Dibandingkan dengan Rp.10,8 Trilliun pada tahun 2014, mencapai Rp.9,1 Triliun pada tahun 2015 , atau turun $15,9 \%$. Penurunan tersebut disebabkan karena meningkatnya rasio kredit bermasalah dari $2 \%$ menjadi $2,7 \%$. Permasalahan bank BNI telah mengurangi kepercayaan masyarakat terhadap bank tersebut, sehingga banyak masyarakat yang enggan menyimpan dananya.

Bank BRI buka sepanjang tahun. Kredit bermasalah yang berpengalaman pada tahun 2014 dan 2018. Terlihat bahwa selama kurun waktu 2014 hingga 2018 terjadi peningkatan kredit macet yaitu $R p$ 6.712.586, Rp 8.752.314, Rp 10.913.507, Rp 12.316.717, dan Rp 20.002.657. Dari tahun 2017 hingga 2018, nilai kredit meningkat sebesar Rp7.685.940. Sehingga jika kualitas kredit memburuk pasti akan menurunkan nilai rasio kecukupan modal. Oleh karena itu, rasio kecukupan modal akan turun dari $22,96 \%$ pada 2017 menjadi $21,21 \%$ pada 2018.

Bagi perbankan, hasil akhir dari penilaian kondisi Bank dapat digunakan sebagai suatu saran dalam menetapkan strategi usaha di waktu yang akan datang namun bagi Bank Indonesia digunakan sebagai saran penetapan dan implementasi strategi pengawasan Bank. Tingkat kesehatan Bank merupakan hasil penilaian kualitatif untuk berbagai aspek yang mempengaruhi kondisi atau kinerja suatu Bank melalui penilaian kuantitatif atau penilaian kualitatif terhadap faktor-faktor CAMEL.(Sumadi, 1970)

Dalam analisis CAMEL dapat diketahui kriteria kesehatan suatu bank yaitu SEHAT,CUKUP SEHAT,KURANG SEHAT,DAN TIDAK SEHAT. Melalui hasil penilaian tersebut maka nantinya bank akan mengambil kebijakan yang berhubungan dengan kinerja bank dimasa yang akan datang. Jika dari hasil penilaian bank dinyatakan sehat maka bank tersebut harus mempertahankan tingkat kesehatannya dan jika dari hasil penilaian bank dinyatakan tidak 
sehat maka bank dinyatakan tidak sehat maka bank tersebut harus meningkatkan tingkat kesehatannya.(Listiawati \& Kurniasari, 2020).

Secara singkat bank yang sehat merupakan bank yang bisa menjalankan fungsinya dengan baik. Bank yang sehat ialah bank yang dapat menjalankan dan memelihara kepercayaan masyarakat, menjalankan fungsi intermediasi, serta membantu kelancaran arus pembayaran yang digunakan pemerintah untuk melaksanakan berbagai kebijakan termasuk kebijakan moneter. Dengan berjalannya fungsi tersebut bank dapat memberikan pelayanan yang baik kepada masyarakat dan bermanfaat untuk semua perbankkan. Kesehatan keuangan bank dan keuangan non-bank adalah kepentingan semua pihak yang terkait, antara lain pemilik, pengelola bank, masyarakat pengguna jasa perbankkan dan Bank Indonesia sebagai otoritas pengawasan perbankkan. Sehingga indikator yang diutamakan dalam laporan keuangan ialah modal, aktiva, manajemen, rentabilitas, dan likuiditas. Hasil akhir penilaian kondisi bank dapat berguna sebagai sarana dalam menetapkan strategi usaha di masa mendatang sedangkan bagi Bank Indonesia digunakan untuk sarana penetapan dan implementasi strategi pengawasan bank oleh Bank Indonesia.(Fitriana, Nur. Rosyid, Ahmad. Fakhrina, 2015).

Dalam suatu perusahaan tentu saja kita menginginkan perusahaan tersebut dalam keadaan sehat, baik dari sisi manajemen maupun dari sisi keuangan. Karena perusahaan yang sehat sudah pasti akan menjalankan roda perusahaan yang tidak dalam waktu singkat, tetapi berkelanjutan dan tentunya akan meningkatkan kinerja perusahaan lebih baik lagi serta meningkatkan laba perusahaan.(Prihatin \& Anjani, 2021) Sehingga penulis meneliti laporan keuangan pada bank dengan menggunakan CAMEL.

\section{METODE}

Riset yang digunakan adalah data sekunder berupa laporan keuangan yang dipublikasikan oleh Bursa Efek Indonesia. Melalui data yang dipakai melalui penelusuran laporan keuangan perusahaan,website www.idx.ac.id. Penelitian ini memakai metode analisis deskriptif yang bersifat kuantitatif yang menjelaskan perbedaan penilaian kesehatan bank yang menggunakan metode CAMEL pada Bank BRI dan Bank BNI. Permodalan ialah bagaimana bank dapat penuhi penilaian permodalan bank, cukupnya penyediaan terhadap aktiva tertimbang menurut resiko $(A T M R)$. Kualitas aset ialah bagaimana Bank memelihara kualitas aktivanya seproduktif mungkin sehingga menjamin hasil yang mendukung rentabilitasnya. Manajemen ialah menilai kualitas manusianya dalam bekerja. Rentabilitas adalah bank yang mampu memenuihi labanya sepanjang periode yang ditentukan. Likuiditas merupakan kemampuan perusahaan untuk memenuihi kewajiban jangka pendeknya pada periode tertentu.

Variabel yang dipakai adalah analisis CAMEL, yang terdiri atas: 1) Capital, diukur untuk bisa mampu memenuhi kewajiban jika terjadinya likuiditas, rasio yang dipakai adalah CAR. 2) Asset, dapat melukiskan kualitas aktiva perusahaan yang ditunjukan untuk bisa mampu dalam menjaga dan mengembalikan dana yang ditanamkan, rasio yang pakai ialah KAP, 3) Management, menggambarkan kualitas manusianya untuk bekerja, rasio yang dipakai ialah NPM, 4) Earning, menggambarkan mampunya perusahaan untuk mendapatkan laba melalui semua kemampuannya, rasio yang dipakai ialah ROA. 5) Liquidity, mampunya bank untuk bisa menyeibangkan antara likuiditasnya dengan rentabilitasnya, rasio yang dipakai ialah LDR.(Rumondor, 2013)

Teknik analisis data yang dipakai ialah metode analisis deskriptif. Metode yang dipakai untuk menganalisis suatu hasil penelitian namun tidak digunakan untuk membuat kesimpulan yang lebih luas. Dengan adanya metode penelitian akan lebih mudah diketahui mengenai tingkat kesehatan bank dengan metode CAMEL pada Bank BRI. Dalam penyusunan laporan usulan penelitian ini mengenai analisis tingkat kesehatan Bank dengan menggunakan rasio CAMEL (studi kasus pada Bank BRI dan Bank BNI) menggunakan analisis deskriptif kuantitatif ialah data yang diperoleh serta dianalisis melalui dasar teori yang 
ada maka dapat memberikan suatu gambaran dan perhitungan yang cukup jelas. Kemudian diteliti diambil suatu kesimpulan dari hasil analisis tersebut, maka dari kesimpulan tersebut diberi saran untuk perbaikan yang diharapkan bisa menjadi bahan pertimbangan bagi perusahaan.(Hendra Saputra, Andi Afrizal, 2016). Agar dapat melakukan pengolahan data dari laporan keuangan maka digunakan analisis rasio CAMEL yaitu CAR, KAP, NPM,ROA, dan LDR.(Sirait \& Pardede, 2020)

Data sekunder merupakan data yang dipakai dalam penelitian ini. Data dikumpulkan oleh peneliti dalam sumber yang telah atau belum dipublikasikan baik dari dalam ataupun dari luar organisasi adalah data sekunder. Yang digunakan untuk laporan keuangan perusahaan yang menjadi sampel pada periode 2014 sampai 2018.

Analisis data adalah bagian yang penting untuk penelitian karena bisa memberikan makna yang sangat berguna untuk bisa memecahkan masalah peneltian. Tujuan analisis data ialah memudahkan data dalam bentuk yang lebih mudah untuk dibacakan. Hal ini dimaksudkan untuk mendapatkan gambaran yang lebih jelas dari kegiatan yang diteliti.(Faisal et al., 2018).

\section{HASIL DAN PEMBAHASAN}

Dari data yang sudah dihitung sedemikian detailnya maka dapat disimpulkan bahwa rasio keuangan pada bank BRI dan bank BNI berada pada predikat SEHAT. Namun dari kedua bank tersebut memiliki keunggulan pada rasio yang berbeda termasuk pada bank BRI unggulnya pada rasio $C A R, K A P, R O A$, dan $L D R$. Sedangkan pada bank BNI hanya unggulnya pada dua rasio saja yaitu NPM dan $L D R$. Maka penilaian kinerja keuangan dengan menggunakan metode CAMEL pada Bank BRI dan Bank BNI pada tahun 2014 sampai 2018 dapat dilihat sebagai berikut.

Tabel 1 dan 2 Perhitungan kinerja keuangan dengan menggunakan metode CAMEL pada Bank BRI dan Bank BNI tahun 2014 - 2018

Tabel 1 : Perhitungan Kinerja Keuangan Dengan Metode CAMEL Pada Bank BRI

$\begin{array}{cccccc}\text { Tahun } & \text { CAR } & \text { KAP } & \text { NPM } & R O A & L D R \\ 2014 & 18,30 & 1,50 & 85,57 & 3,95 & 81,67 \\ 2015 & 20,58 & 1,86 & 79,45 & 3,80 & 86,88 \\ 2016 & 22,91 & 2,06 & 77,04 & 3,46 & 87,76 \\ 2017 & 22,96 & 2,38 & 78,73 & 3,37 & 88,13 \\ 2018 & 21,21 & 2,45 & 77,71 & 3,30 & 89,56\end{array}$

Sumber :(Bank Rakyat Indonesia, 2018)

Tabel 2 : Perhitungan Kinerja Keuangan Dengan Metode CAMEL Pada Bank BNI

\begin{tabular}{cccccc}
\hline Tahun & CAR & KAP & NPM & ROA & LDR \\
\hline 2014 & 16,21 & 1,62 & 82,83 & 3,32 & 87,81 \\
2015 & 16,21 & 1,81 & 82,60 & 2,25 & 87,76 \\
2016 & 19,35 & 2,38 & 80,73 & 2,39 & 90,40 \\
2017 & 18,52 & 1,78 & 80,57 & 2,46 & 85,57 \\
2018 & 18,50 & 1,38 & 78,25 & 2,52 & 88,75 \\
\hline
\end{tabular}

Sumber: (Bank Rakyat Indonesia, 2018)

Dari hasil yang sudah dihitung maka hasil penelitian ini di hubungan dengan penelitian terdahulu bahwa keduanya bersamaan meneliti di PT. Bank Rakyat Indonesia (persero) Tbk namun rasio yang digunakannya sedikit berbeda yang dimana pada penelitian terdahulu melakukan rasio pada CAR, KAP, ROA, LDR, PPAP, BOPO, DAN IER sedangkan pada penelitian diatas hanya menggunakan CAR, KAP, ROA, NPM, dan LDR.

Kinerja keuangan dilakukan untuk menilai kondisi keuangan serta prestasi perusahaan, analisis adalah tolak ukur yang dipakai melalui rasio atau indeks yang dihubungkan dengan dua data keuangan satu dengan lainnya.(Mudhara $m$ Abah, 2017). Kondisi keuangan Bank $\mathrm{BRI}$ dan BNI setiap tahunnya berfluktuasi sehingga dilakukan penelitian secara detail agar 
dapat diketahui sampai dimana prestasi keuangan yang dipegang oleh kedua bank dengan menggunakan tolak ukur dari rasio. Maka disimpulkan bahwa kedua bank masih memegang predikat yang baik walaupun dapat dikatakan masih ada banyak kekurangan dari bank BNI pada rasio KAP yang pada tahun 2018 menurun menjadi 1,38\% namun masih berada pada predikat yang sehat.

Menurut ketentuan Bank Indonesia bahwa peringkat tingkat kesehatan bank dapat dikelompokkan sebagai berikut:

Tabel 3. Peringkat Kesehatan Bank

\begin{tabular}{cc}
\hline Nilai CAMEL(\%) & Predikat \\
\hline $81-100$ & SEHAT \\
$66-80$ & CUKUP SEHAT \\
$51-67$ & KURANG SEHAT \\
$0<51$ & TIDAK SEHAT
\end{tabular}

Sumber : (Kaligis, 2013)

Tabel 4

Predikat Peningkat kesehatan pada Bank BRI Tahun 2014-2018

\begin{tabular}{cccc}
\hline NAMA BANK & TAHUN & NILAI CAMEL (\%) & PREDIKAT \\
\hline \multirow{4}{*}{ BRI } & 2014 & 85,43 & SEHAT \\
& 2015 & 83,62 & SEHAT \\
& 2016 & 82,8 & SEHAT \\
& 2017 & 82,6 & SEHAT \\
& 2018 & 82,29 & SEHAT \\
\hline
\end{tabular}

Tabel 5

Predikat peningkat kesehatan pada Bank BNI Tahun 2014-2018

\begin{tabular}{cccc}
\hline NAMA BANK & TAHUN & NILAI CAMEL (\%) & PREDIKAT \\
\hline & 2014 & 84,46 & SEHAT \\
BNI & 2015 & 84,33 & SEHAT \\
& 2016 & 83 & SEHAT \\
& 2017 & 83,97 & SEHAT \\
& 2018 & 84,18 & SEHAT \\
\hline
\end{tabular}

Menurut (sutrisno, 53;2009) Kinerja keuangan perusahaan merupakan prestasi yang telah dicapai perusahaan untuk satu periode berjalan yang mencerminkan tingkat kesehatan perusahaan tersebut. Bank BRI dan BNI dapat mencapai predikat yang baik pada lima periode tertentu dikarenakan kinerja keuangannya boleh bertahan pada predikat yang baik walaupun nilainya berfluktuasi setiap tahunnya namun masih memegang predikat yang baik.

\section{KESIMPULAN DAN SARAN}

Metode CAMEL menjadi referensi dalam pemeriksaan kinerja keuangan pada kedua bank sehingga dapat dilihat bahwa bank BRI dan BNI selama lima tahun terakhir berada pada predikat yang SEHAT.

Menurut penulis jika selanjutnya ada yang mau melakukan penelitian yang serupa maka disarankan agar melakukan penelitian di perusahaan yang berbeda dan lebih mempelajari tentang kinerja keuangan pada perusahaan dengan motode camel. 


\section{DAFTAR PUSTAKA}

Analisis Laporan Keuangan - Google Books. (n.d.). Retrieved July 29, 2021, from https://www.google.co.id/books/edition/Analisis_Laporan_Keuangan/SC7GDwAAQBAJ? $\mathrm{hl}=\mathrm{id} \& g \mathrm{bpv}=1 \& \mathrm{dq}=$ tujuan+laporan+keuangan+sutrisno+(2009:53)\&printsec=frontcover

Bank Rakyat Indonesia. (2018). Digitalisasi layanan perbankan. 1291.

Camel, M., Ekonomi, F., Manajemen, P. M., Ratulangi, U. S., \& Chandra, R. (2016). Analisis Kinerja Keuangan Pt Bank Syariah Mandiri Dan Pt Bank Mandiri Tbk Dengan Menggunakan Metode Camel. Jurnal Berkala IImiah Efisiensi, 16(2), 2010-2016.

dwi safrisal.pdf. (n.d.).

Faisal, A., Samben, R., \& Pattisahusiwa, S. (2018). Analisis kinerja keuangan. Kinerja, 14(1), 6. https://doi.org/10.29264/jkin.v14i1.2444

Hendra Saputra, Andi Afrizal, M. (2016). Analisis Tingkat Kesehatan Bank Dengan Menggunakan Metode Camel Pada PT. Bank Rakyat Indonesia Tbk. Bisnis Administrasi, 5, 45.

Istikomah. (2014). No 主観的健康感を中心とした在宅高齢者における健康関連指標に関する 共分散構造分析Title.

Kaligis, Y. (2013). Analisis Tingkat Kesehatan Bank Dengan Menggunakan Metode Camel Pada Industri Perbankan Bumn Yang Terdaftar Di Bursa Efek Indonesia. Jurnal Riset Ekonomi, Manajemen, Bisnis Dan Akuntansi, 1(3), 263-272. https://doi.org/10.35794/emba.v1i3.2015

Lhokseumawe, P. N., Pengantar, K., Alwie, rahayu deny danar dan alvi furwanti, Prasetio, A. B., \& Andespa, R. (2010). Tugas Akhir Tugas Akhir. Jurnal Ekonomi Volume 18, Nomor 1 Maret201, 2(1), 41-49.

Manajemen, J., No, V., Zami, A., Tinggi, S., \& Ekonomi, I. (2017). Jurnal Manajemen dan Perbankan Vol. 4 No. 1. 4(1), 72-91.

Manajemen Keuangan: Sebagai Dasar Pengeambilan Keputusan Bisnis - Rajawali ... Google Books. (n.d.). Retrieved July 28, 2021, from

https://www.google.co.id/books/edition/Manajemen_Keuangan_Sebagai_Dasar_Penge $\mathrm{am} / \mathrm{h} 2$ YhEAAAQBAJ?hl=id\&gbpv=1\&dq=sutrisno+2009\%3B53\&pg=PA135\&printsec=fr ontcover

Mudhara $m$ abah. (2017).

Pada, C., Bri, B., Bank, D. A. N., Periode, B. N. I., Kalendesang, A. C., Pangemanan, S. S., \& Gerungai, N. Y. T. (2017). 1, 2 , 3 1. 12(1), 10-19.

Rumondor, R. (2013). Perbandingan Kinerja Keuangan Bank Mandiri, Bri Dan Bni Yang Terdaftar Di Bursa Efek Indonesia. Jurnal Riset Ekonomi, Manajemen, Bisnis Dan Akuntansi, 1(3), 782-792.

Sirait, S., \& Pardede, H. D. (2020). Analisis Kinerja Keuangan Pt Bank Rakyat Indonesia (Persero), Tbk. Jurnal Ekonomi Dan Bisnis (EK\&BI), 3(2), 313-323. https://doi.org/10.37600/ekbi.v3i2.197

UMA. (2013). Jurnal Universitas Medan Area. Jurnal Universitas Medan Area, 53(1), 3-4. http://dx.doi.org/10.1016/j.encep.2012.03.001

v. M. buyanov. (1967). 済無No Title No Title No Title. Angewandte Chemie International Edition, 6(11), 951-952., 15(1), 49-57. 